\title{
The evaluation of venture capital investments using real option approach
}

\author{
Alexandra Posza \\ University of Pécs
}

\section{THE AIMS OF THE PAPER}

This study attempts to explore the links between venture capital (VC) investments and the real option approach (ROA) with analyzing the characteristic features of the venture capital investments and their process. The real options can be examined as a way of thinking and evaluation method and the study's aim is to show that real option approach can provide an answer to the valuation challenges of venture capital investments.

\section{METHODOLOGY}

The choice of the appropriate valuation method requires consideration of its conditions of application, which, in the case of real option theory, result from the examination of uncertainty, flexibility and irreversibility. The venture capital investments are characterized by a high degree of uncertainty and risk, which can also be traced back to the provision of financing to innovative, early-stage companies. Real option theory also provides venture capital investors with professional experience through their active role in decision-making. The study evaluates a Hungarian start-up company venture capital investment with the help of a traditional discounted cash flow method and two real option valuation models: Black - Scholes model and binomial pricing model. Then a sensitivity analysis is prepared to analyze the value driver effect on option value and a volatility analysis to verify the importance of high-degree of uncertainty in real option valuation.

\section{MOST IMPORTANT RESULTS}

The paper concludes that the option-based valuation methods are more suitable for evaluating venture capital investments than other approaches such as the discounted cash flow methods, and the embedded flexibility can be determined by the real option approach. The binomial pricing model points out the advantages of staging investments with the higher real (call) option value. Besides the real option valuation, the sensitivity analysis shows a positive effect of the present value of the underlying assets, the time to maturity, the risk-free interest rate and volatility on the call option value. The analysis of the volatility emphasizes the importance of the degree of uncertainty in real option valuation.

\section{RECOMMENDATIONS}

The real option approach ensures proper evaluation of venture capital investment, avoiding the undervaluation and taking advantage of staging and timing investments in practice.

Keywords: real option theory, venture capital investment, strategic flexibility, uncertainty

Acknowledgment: Supported by the ÚNKP-19-3 New National Excellence Program of the Ministry for Innovation and Technology

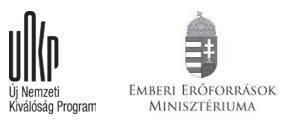

DOI: 10.15170/MM.2020.54.02.02 


\section{INTRODUCTION}

Entrepreneurs face the question of financing and its possible sources at first when setting up their business. According to EBAN (2009), the fundraising can be interpreted as a process that highlights the characteristics and development potential of companies or business ideas and directs it towards the appropriate financing source, so that it can decide on the capital provided by banks, business angels and venture capital funds.

Venture capital is one possible form of private equity financing (Landström 2007, Metrick - Yasuda 2011) and a significant financial source for innovative and high-risk start-ups (Cassar 2004, Ko et al. 2011). In the case of venture capital, the investor appears as a financial intermediary of a non-financial corporation (Maula 2007), the primary reward available to the investor is the capital gains (Lorenz 1989).

At the outset of venture capital investments, venture capitalists were not equipped with the project and corporate valuation methodologies. Over the years, they began to develop their valuation systems and tried to acquire existing valuation techniques. They award business ventures by intuition and quantitative valuation techniques, but to make the right investment decision, they are increasingly favoring the latter. Among the valuation methods, discounted cash flow methods play a significant role, but there is not sufficient information about the current and past years of business operations. In addition, comparable companies and useful market information are rarely available. All of these factors restrain the use of these methods.

Venture capital funds have many options due to the uncertainty of future developments and embedded flexibility in venture capitalist decision-making. The venture capital investments are surrounded by a high degree of uncertainty (Bygrave et al. 1989), and the venture capitalists need to find an investment strategy that can deal with it. The real option theory can effectively handle uncertainty in the value of high-tech companies and reflects the value of flexibility, thus exceeding the limits of the discounted cash flow method.

The discount cash flow (DCF) methods assume passive management (Kogut \& Kulatilaka 1994) and disregard the added value that can be incorporated in a project employing the management's flexible adaptation and innovation, and they systematically underestimate the value of investment projects (Dixit - Pindyck 1994, Trigeorgis 1993). The undervaluation of investment alternatives may lead to underinvestment and losing the competitive position (Dean 1951, Hayes - Abernathy 1980). An efficient project valuation procedure takes both uncertainty and active decision-making - essential to the success of a strategy - into account (Luehrman 1998).

The venture capitalist's investment activity is described as a five-step sequential, systematic process according to Tyebjee \& Bruno (1984), which includes investment origination, screening, valuation, structuring, and post-investment phases. The venture capitalists first recognize an investment opportunity, and in the second step, filter potential investments, focusing primarily on those that belong to their field in terms of technology, product, and market. According to Gompers (1995), venture capitalists review the business plan of their young venture at this stage. In the third evaluation phase, future returns and risks are estimated based on financial, accounting (Wright \& Robbie 1996), and other qualitative and relevant information. The fourth stage occurs when the valuation has led to a positive outcome, and venture capital investors begin the process of negotiating with the potential entrepreneur regarding the amount invested, its form and price. The final phase is the post-investment activity, which is a formal representation of the company owner and coordination with the company management. In this final stage venture capitalists help entrepreneurs to find exit opportunities through acquisitions, mergers or exchanges and IPO (Lee 2018).

The paper attempts to provide an answer to the valuation challenges of venture capital investments and explore the links between venture capital (VC) investments and the real option approach (ROA) with analyzing the characteristic features of the venture capital investments and their process.

\section{THE REAL OPTION APPROACH (ROA)}

Real options are „investments in physical assets, human resources, and organizational capabilities that respond to future potential events" (Kogut \& Kulatilaka 2001, 3). These are similar to financial options because these also give a right but not obligation to buy or sell the underlying asset for a prescribed price at a predetermined time (Copeland \& Antikarov 2001). In the real option approach, uncertainty has value due to the ability of managers to actively manage uncertain projects (Boyer et al. 2003, Herder et al. 2011), that is, to incorporate flexibility into the managerial toolbox. According 
to Triantis \& Borison (2001), the real option theory can be interpreted on three levels, such as the way of thinking, the analytical tool and the organizational process. In the first case, it is primarily viewed as a language that qualitatively frames decision-making problems. In the second case, the real option valuation procedures are used to evaluate projects, and the third option is the organizational process, in which it plays a role as a management tool that defines and exploits strategic options as part of a broader process.

This approach appears in real options' strategic management application that starts with identifying single and complex existing options with the help of individual competencies and then, in the second step, evaluate theses real options with the right valuation methods. It is followed by real options' management and in the last step, the strategic decision, that includes the staging, exiting and timing decisions (Csapi 2019). The strategic real option management phases with the before mentioned venture capital investment process are connected in Table 1. According to Trigeorgis \& Reuer (2017), the first two steps (three in the case of VC) build on the individuals' competencies, the management of the real option portfolio is based on the organizational and behavioral characteristics and the strategic decision is mostly intuition-based. The mutual phase of these processes is the valuation that consists of both qualitative and quantitative analysis and already in the second step of the venture capital process is possible to identify real options that can be managed and exercise during the project.

Table 1. Connection between venture capital investment activity and strategic real option management

\begin{tabular}{|c|c|c|c|c|c|c|}
\hline \multicolumn{3}{|c|}{ Strategic real option management } & \multicolumn{3}{|c|}{ Process of venture capital investment } & Used competencies \\
\hline & & & Phase 1 & $\begin{array}{l}\text { Recognition } \\
\text { opportunity }\end{array}$ & $\begin{array}{l}\text { f investment } \\
\text { rigination) }\end{array}$ & \multirow{4}{*}{$\begin{array}{l}\text { Individual } \\
\text { competencies }\end{array}$} \\
\hline Phase 1 & $\begin{array}{l}\text { Identificatic } \\
\text { (strategic al }\end{array}$ & $\begin{array}{l}\text { of real options } \\
\text { lysis) }\end{array}$ & Phase 2 & $\begin{array}{l}\text { Filter poten } \\
\text { (screening) }\end{array}$ & 1 investment & \\
\hline \multirow{2}{*}{ Phase 2} & Real option & aluation & \multirow{2}{*}{ Phase 3} & \multicolumn{2}{|l|}{ Valuation } & \\
\hline & qualitative & quantitative & & qualitative & quantitative & \\
\hline Phase 3 & \multicolumn{2}{|c|}{$\begin{array}{l}\text { Real option management } \\
\text { (application) }\end{array}$} & Phase 4 & Structuring & & $\begin{array}{l}\text { Organizational } \\
\text { behavioral } \\
\text { characteristics }\end{array}$ \\
\hline Phase 4 & \multicolumn{2}{|c|}{$\begin{array}{l}\text { Real option exercise } \\
\text { (strategic decision) }\end{array}$} & Phase 5 & \multicolumn{2}{|c|}{ Post-investment activity } & Intuitions \\
\hline
\end{tabular}

Source: own construction according to Tyebjee \& Bruno 1984, Trigeorgis \& Reuer 2017, Csapi 2019

During the real option management, the different types of real options provide a framework for analyzing real options, which help to operationalize and support decision thinking. Trigeorgis (1996) differentiated the option to defer, option to reject, option to alter (expand or shutdown), option to switch, option to growth, option to stage, and compound real options. The value of the option to defer is derived from providing the company with the ability to shift the investment decision over time to obtain new information that may remedy or reduce existing uncertainty (Rózsa 2004). The option to reject is the abandonment of all or part of the project and the permanent liquidation of the investment if the market situation turns unfavorable. According to Huang \& Chou (2006), the real option of dropping an investment project is being protected against future operating losses. Option to switch (shutdown and restart options) allows market management to decide to stop production in adverse market conditions but do not rule out the possibility of a restart (Csapi 2018). Option to alter includes the option to expand and option to contract that can be used in the event of a permanent and 
significant improvement or deterioration in market conditions. Growth options are similar to the option to expand, but the difference lies in their place within the corporate strategy. Growth options provide project-wide flexibility, while expansion and staging options appear as project-wide options. In the case of staging (time-to-build) options, project managers can split investment projects into phases and then transfer the experience from the earlier periods to the later phases. Each stage of the project is evaluated, and management can decide whether to continue or reject the project (Scialdone 2007).

As a result of active management and multistage nature of venture capital investments, venture capitalists can utilize the new information during the project lifetime. The early-stage companies require periodic investments, which can be considered as a multi-phase (complex) call option. The stages of venture capital investments are the seed, start-up, early-stage, expansion, acquisition, and turnaround, while Gong et al. (2006) investigate the seed, start-up growth expansion, bridge and exit (IPO) stages (Figure 1). Investments can be examined along these stages, and real options can be identified through this process. The venture capital investors have the right to choose the time and the phase of the investment, i. e. they have timing (call), growth and staging real options that allow them to modify the investment. In addition, based on the information available, they have the right to reject or suspend the project, which is real option to abandon (put option). The higher frequency of milestones and funding rounds should result in a more compelling investment strategy and, consequently, lower agency costs and better investment performance (Gompers 1995).

Figure 1. Real options in staged investments

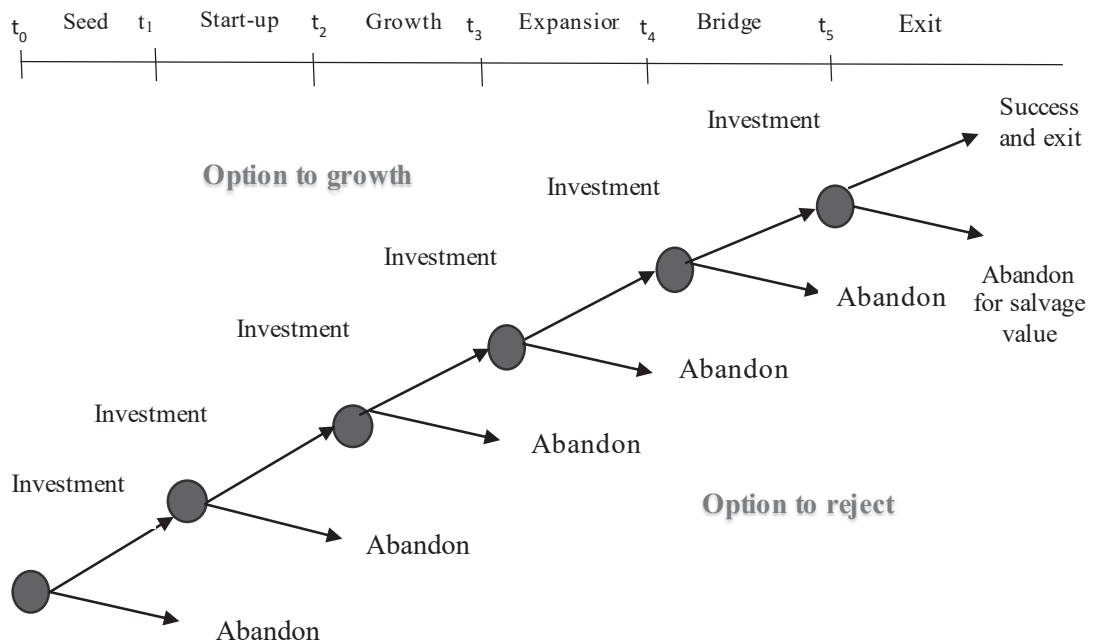

Option to stage

Source: own construction according to Gong et al. 2006 


\section{REAL OPTIONS AND VALUATION}

The study is focusing on the valuation of venture capital investments, which is also an essential and critical part of the entire venture capital investment operating process. The assessment of venture capital investments can be divided into qualitative and quantitative approaches. In a qualitative approach to evaluating venture capital investment, Tyebjee \& Bruno (1984) consider management as the most critical factor, that is followed by market growth, then examine the entrepreneur's personality and experience. Kaplan \& Stromberg (2000) complements Tyebjee \& Bruno 's (1984) approach with corporate strategy, as well as technical competitiveness. Besides, Fried and Hisrich (1994) emphasize the viability of the project, the unity of the management team, business performance and leadership capabilities, and the likelihood of an easy exit to obtain high returns.

From a quantitative point of view, the valuation procedures that are used for the assessment of venture capital investments come to the front. Wright et al. (2004) consider the used valuation procedures and the related information that is available to venture capital companies crucial. The traditional venture capital valuation process involves the analysis of future cash flows, stock prices and stock market performance of comparable companies, and the calculation of $\mathrm{P} / \mathrm{E}$ (Price-to-Earnings) or $\mathrm{P} / \mathrm{S}$ (Price-to-Sales) ratios (Seppä \& Laamanen 2001). According to Karsai et al. (1998), discounted cash flow (DCF) based procedures may raise valuation problems in uncertain environments. DCF methods can only handle the value determination process in a deterministic way (Takács 2014). When evaluating strategic investments with high levels of uncertainty, the use of the DCF method may result in limited or misleading values (Adler 2000, Park \& Herath 2000, Yeo \& Qiu 2003, Pless et al. 2016). Option theory can provide an answer to the valuation challenges of venture capital investments with high growth potential and uncertainty.

Real option valuation procedures fall into two major analytical and numerical categories (Schulmerich 2010). Analytical methods include closed-form models and approximation methods. Closed-form models use formulas to value an option, thus simplifying the procedure (Adetunji \& Owolabi 2016) but the relationship between the valuation parameters needs to be examined (Hartmann 2006). Analytical methods include the Black-Scholes model, which is widely used to evaluate real options. Numerical methods lead to solutions through the underlying stochastic process or partial differential equations. Frequently used methods for estimating stochastic processes are Monte Carlo simulations, binomial pricing models and decision trees. Willner (1995) was one of the first to model the value of start-up companies, concluding that many start-up companies have the characteristics of a growth option. Jägle (1999) proposes binomial pricing for the evaluation of sequential processes, and Smith \& McCardle (1998) also emphasizes that decision trees are most capable of displaying the flexibility of decision making. Cox, Ross, and Rubinstein (1979) introduced the binomial pricing model as a numerical approximation method that became widely used in European and American-type option valuation. To determine the value of options with the binomial option pricing model actually means a process of solving a decision tree (Brealey \& Myers 2005), and that estimates the value of an option at time $\mathrm{t}=0$.

The other option valuation model, the Black Scholes model was a breakthrough in economics in 1973, being the first one-period model to price European options. The model is deterministic, and it does not assume the presence of stochastic elements in the variability of volatility and it assumes constant volatility of returns over a short period. The Black-Scholes model was created to financial option evaluation, but this six value drivers' correspond to the parameters of real option theory that was first summarized by Luehrman (1998), and the analogy between these option theories in Table 2 . 
Table 2. The analogy between financial and real options

\begin{tabular}{|l|l|l|}
\hline Financial option & Variable & Real option \\
\hline Stock price & $\mathrm{S}$ & Present value of the project's operating assets to be acquired \\
\hline Strike price & $\mathrm{X}$ & Expenditure required to acquire the project assets \\
\hline Time to expiration & $\mathrm{t}$ & Length of time the decision may be deferred \\
\hline Variance of returns on stock & $\mathrm{\sigma}$ & Riskiness of project assets \\
\hline Risk-free rate & $\mathrm{r}$ & Time value of money \\
\hline
\end{tabular}

Source: Own construction according to Luehrman 1998

Identifying these parameters secures the option evaluation. There are many criticisms for defining the volatility. The measure of volatility can be estimated by different indices of natural logarithmic-based profitability, historical volatility, Monte Carlo simulation, and substitution in the market. The uncertainty of the underlying asset is calculated with equation (1) that is expressed in form of Gauss Wiener process in Equation (2), and call option value can be calculated with Equation (3) (Sung \& Park 2017).

$$
\begin{array}{r}
d S_{t}=a S_{t} d t+\sigma S_{t} d z \\
d \ln S_{t}=\left[a-\frac{1}{2} \sigma^{2}\right] d t+\sigma d z \\
c=S * N\left(d_{1}\right)-X * e^{-r t} * N\left(d_{2}\right) \\
d_{1}=\frac{\ln \left(\frac{S}{X}\right)+\left(r+\sigma^{2} / 2\right) T}{\sigma \sqrt{T}} \\
d_{2}=d_{1}-\sigma \sqrt{T}
\end{array}
$$

where $\mathrm{c}$ is the current value of the call option, $\mathrm{S}$ is the present value of the underlying asset, $N\left(d_{i}\right)$ is the probability that the value of a randomly selected number from a set of normally distributed numbers is less than $d_{i}, X$ is the strike price of the option, $r$ is the risk-free interest rate, $\mathrm{T}$ is the maturity of the option, $\sigma^{2}$ is the variance of the underlying asset, $\mathrm{a}$ is the growth rate of the underlying asset, and $\mathrm{dz}$ is the increment in Gauss Wiener Process.

The option value is an incremental function for $\frac{S}{X}$, rT and $\sigma \sqrt{T}$. Moreover, in order to have an intrinsic value of underlying assets $\mathrm{S}$ must be greater or equal than the expenditure required to acquire the project assets $(\mathrm{X})$. The volatility can be determined, as mentioned before, by the Monte Carlo Simulation Method that uses the present value of cash flows $\left(\mathrm{CF}_{\mathrm{i}}\right)$ to generate $\mathrm{CF}_{\mathrm{i}}$ 's under uniform distribution at each iteration of the simulation, where the lower and upper bound are determined by min $\left(\mathrm{CF}_{\mathrm{i}}\right)$ and $\max \left(\mathrm{CF}_{\mathrm{i}}\right)$ and estimate the volatility of the variance of $Y=\ln \frac{P V_{n}}{P V_{n}}$ according to the number of iterations (Sung $\&$ Park 2017).

According to Sung - Park (2017), the real option-based value does not reflect the variance under some condition e.g., revenue period is relatively short (2-3 years) when it is applied to evaluate new technology or investment project. The paper shows how volatility in the Black-Scholes model appears and tries to determine a certain degree of volatility, which reflects future uncertainty of decision making in the option value.

\section{METHODOLOGY}

In general, the choice of the appropriate valuation method requires consideration of its conditions of application, which, in the case of real option theory, result from the examination of uncertainty, flexibility and irreversibility. The venture capital investments are characterized by a high degree of uncertainty and risk, which can also be traced back to the provision of financing to innovative, early-stage companies. The venture capital financing process is continuously influenced by idiosyncratic uncertainties (Davis et al. 2004, Li 2008, Pennings \& Lint 1997, Wang \& Zhou 2004). Real option theory provides venture capital investors with professional experience through their active role in decisionmaking (Carvalho et al. 2005). Venture capital projects are sequential investment decisions in which the venture capital investor has to decide whether to continue investing in the project or not (exit) (Sahlman 1990, Gompers 1995, Gompers \& Lerner 
1999, Dahiya \& Ray 2010). According to Landier (2002), staging is one way to protect an investor from risk when entrepreneurs have an exit option. Determining how to make a successful decision in a venture capital project is a complex investment problem that also arises from the characteristics of funded companies (Miltersen \& Schwartz 2002).

The real option theory can be interpreted not only in theory but also in practice, which has been illustrated through a case study. The based DCF analysis is carried out from a venture capital fund that is completed with a real option analysis with the aim to show the value of the embedded flexibility, effects of the volatility and the use of real option approach in venture capital investments. In the heart of the analysis stands a Hungarian start-up company that gets two-round venture capital financing in its seed and start-up stage that can be interpreted as a compound (call) option. However, the growth plans of the company are surrounded by considerable uncertainty, the project carries the potential for postponement and staging, which means with enough managerial flexibility, the plans can be feasible.

At first, venture capital investment was evaluated using the traditional DCF method. The Free Cash Flow to Firm (FCFF) value is $106,074,000$ HUF (cost of capital: $7.34 \%$ ), which can be used to calculate the value of the company by taking into account two stages of venture capital investment $(39,000,000 \mathrm{HUF})$, so in this case, it is $67,074,000$ HUF.

Table 3. Input parameters of the real option valuation

\begin{tabular}{|l|l|l|}
\hline Input parameters & Variable & Values \\
\hline Underlying asset value (PV(FCFF)) & $\mathrm{S}$ & $106,074,000 \mathrm{HUF}$ \\
\hline $\begin{array}{l}\text { Exercise Price (venture capital } \\
\text { investment) }\end{array}$ & $\mathrm{X}$ & $\begin{array}{l}39,000,000 \mathrm{HUF}(\mathrm{X} 1=9,000,000 \mathrm{HUF}, \\
\mathrm{X} 2=30,000,000 \mathrm{HUF})\end{array}$ \\
\hline Time to expiration & $\mathrm{t}$ & 1.5 year \\
\hline Volatility & $\sigma$ & $64.46 \%$ \\
\hline Risk-free interest rate & $\mathrm{r}$ & $2.5 \%$ \\
\hline
\end{tabular}

Source: own construction

According to the parameters of Table 3, the call option value with Black - Scholes model is $70,589,708$ HUF that shows the embedded flexibility in the model that is equal to the difference between the call option value and FCFF value, so 3,515,708 HUF.
The other frequently used real option evaluation method is the binomial pricing model that was also calculated in the case of the venture capital investment. The calculated parameters of the model can be seen in Table 4.

Table 4. Calculated parameters of the binomial pricing model

\begin{tabular}{|l|l|l|}
\hline Parameters & Variables & Values \\
\hline Length of periods & $\Delta \mathrm{t}$ & 0.25 \\
\hline Upside parameter & $\mathrm{u}$ & 1.38 \\
\hline Downside parameter & $\mathrm{d}$ & 0.72 \\
\hline Risk-neutral probability & $\mathrm{q}$ & 0.46 \\
\hline
\end{tabular}

Source: own construction 
With the help of the input and the calculated parameters, the underlying asset values and the call option values were computed, and the call option value is equal to $71,610,807$ HUF.

The result shows that the DCF method gave the lowest company value in the case of venture capital investment that is followed by the Black-Scholes model value, and the highest value was generated by the binomial pricing model that demonstrates a higher level of strategic flexibility, certified staging advantages and value-creating role.

In order to find out what value driver makes the most significant impact on the option value, a sensitivity analysis is prepared. Suppose that each input parameters deviate by $1 \%$. According to the results of the sensitivity analysis (Figure 2), the deviation of the present value of the underlying asset has the most significant impact on the option value, and positive relationships can also be identified between the option value and volatility and risk-free rate. In contrast, an increase in exercise price results in decreasing call option value.

Figure 2. Sensitivity analysis of option value

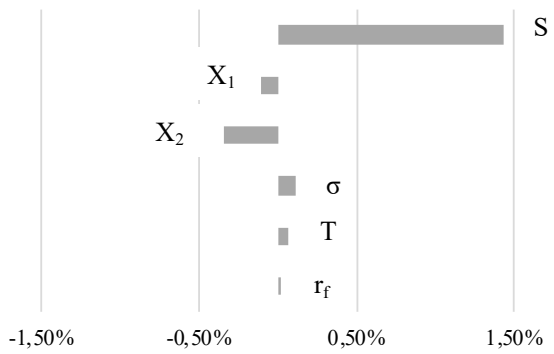

\section{Source: own construction}

In the sensitivity analysis, the volatility value creation ability can be seen but it can not get a massive role in option value. In order to analyze the effective region of volatility the „no action taken” (NAT) region needs to be found and it corresponds to zero option value, that can be calculated with the ratio (nominated with $\mathrm{R}$ ) of the exercise price, $\mathrm{X}$ (here the venture capital investments) to the value of the underlying asset (in this case $\mathrm{PV}(\mathrm{FCFF})$ ) (Sung \& Park 2017).
Figure 3. Real option value (V) and Threshold value $\mathbf{R}^{\text {th }}$

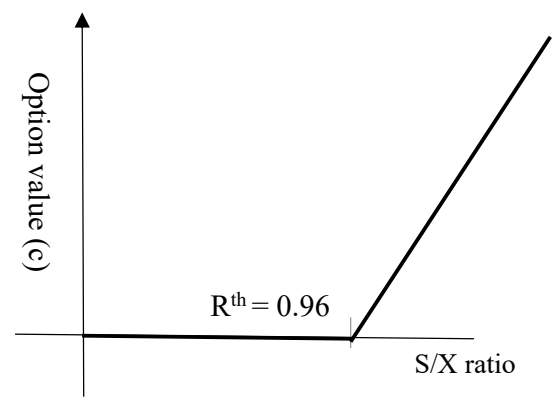

Source: own construction

In the analysis, the timespan for the investment is considered to 1.5 years, with the risk-free interest rate of $2.5 \%$. The $\mathrm{R}$ value is not always valid for all values of volatility, therefore the region where the option value is zero needs to be found. Below the threshold value $\left(\mathrm{R}^{\text {th }}=e^{-r t}=0.96\right)$ exists the NAT region where the value of the underlying assets is 0.96 times the exercise price (the venture capital investment) (Figure 3).

The analysis of the volatility shows that if the volatility is lower than $5 \%$, the option value is very close to zero (Table 5), that is why it cannot create value for the option holder. It confirms that real options are valuable in the case of a high degree of uncertainty and option valuation models are appropriate to evaluate the young, innovative companies. 


\begin{tabular}{|c|c|c|c|c|c|c|c|c|c|c|c|}
\hline$\stackrel{\Re}{\not}$ & 0 & 公 & $\stackrel{z}{\underline{e}}$ & $\stackrel{2}{N}$ & $\cong$ & $\stackrel{2}{3}$ & $x$ & in & क & $\rightarrow$ & $a_{n}$ \\
\hline $\begin{array}{l}\stackrel{\circ}{8} \\
\dot{8} \\
\pm\end{array}$ & $\begin{array}{l}\stackrel{\circ}{\circ} \\
\dot{8} \\
\dot{1}\end{array}$ & 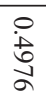 & 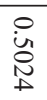 & $\begin{array}{l}\dot{0} \\
\dot{8} \\
\dot{0}\end{array}$ & $\begin{array}{l}\stackrel{\circ}{8} \\
\stackrel{8}{\sigma}\end{array}$ & $\begin{array}{l}\stackrel{8}{0} \\
\text { 岕 }\end{array}$ & - & $\begin{array}{l}\stackrel{\circ}{\circ} \\
\text { 心్N }\end{array}$ & $\begin{array}{l}N \\
\ddot{y} \\
\text { Oे }\end{array}$ & is & $\begin{array}{l}\stackrel{\circ}{\circ} \\
\stackrel{0}{\circ}\end{array}$ \\
\hline $\begin{array}{l}\stackrel{\circ}{0} \\
\stackrel{w}{w} \\
\stackrel{\omega}{\omega}\end{array}$ & $\begin{array}{l}\stackrel{0}{0} \\
\dot{w} \\
\dot{w}\end{array}$ & 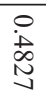 & $\begin{array}{l}\stackrel{0}{\dot{u}} \\
\underset{w}{w}\end{array}$ & $\begin{array}{l}\dot{b} \\
\dot{+} \\
\dot{\omega} \\
\text { d. }\end{array}$ & 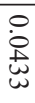 & $\begin{array}{l}\stackrel{\circ}{\circ} \\
\text { 岕 }\end{array}$ & - & 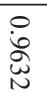 & $\begin{array}{l}N \\
\dot{y} \\
\text { o } \\
\text { o }\end{array}$ & $\overline{i_{1}}$ & $\begin{array}{l}0 \\
\text { un } \\
\text { oे }\end{array}$ \\
\hline $\begin{array}{l}\dot{\circ} \\
\dot{\&} \\
\text { ¿े }\end{array}$ & 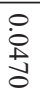 & $\begin{array}{l}\circ \\
\text { A } \\
\text { ă }\end{array}$ & $\begin{array}{l}\text { O } \\
\text { 崩 } \\
+\end{array}$ & $\begin{array}{l}\dot{d} \\
\dot{\circ} \\
\dot{2}\end{array}$ & $\begin{array}{l}\stackrel{\circ}{\circ} \\
\stackrel{\circ}{N}\end{array}$ & $\begin{array}{l}\circ \\
\dot{\circ} \\
\text { 岕 }\end{array}$ & - & $\begin{array}{l}\stackrel{\circ}{\dot{\circ}} \\
\text { 岕 }\end{array}$ & $\begin{array}{l}\text { Nu } \\
\text { :i } \\
\text { o }\end{array}$ & $\overline{i_{1}}$ & $\bar{\sigma}^{\circ}$ \\
\hline $\begin{array}{l}\stackrel{\circ}{\dot{D}} \\
\stackrel{\infty}{\not}\end{array}$ & $\begin{array}{l}\stackrel{\circ}{\circ} \\
\dot{\infty} \\
\stackrel{D}{\not}\end{array}$ & $\begin{array}{l}\stackrel{\circ}{\text { D }} \\
\stackrel{\Delta}{\Delta}\end{array}$ & 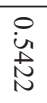 & $\begin{array}{l}\dot{0} \\
\dot{0} \\
\vdots\end{array}$ & $\begin{array}{l}\stackrel{\circ}{\circ} \\
\stackrel{\circ}{\circ}\end{array}$ & $\begin{array}{l}\text { O } \\
\text { 岕 }\end{array}$ & - & $\begin{array}{l}\stackrel{\circ}{\circ} \\
\text { 岕 }\end{array}$ & $\begin{array}{l}\text { Nu} \\
\ddot{o} \\
\text { o. }\end{array}$ & $\overrightarrow{u_{r}}$ & $\ddot{\omega}$ \\
\hline $\begin{array}{l}\stackrel{0}{0} \\
\dot{0}\end{array}$ & $\begin{array}{l}\stackrel{0}{0} \\
\stackrel{8}{0}\end{array}$ & $\begin{array}{l}\stackrel{\circ}{0} \\
+ \\
\stackrel{+}{u}\end{array}$ & $\begin{array}{l}\circ \\
\text { 崩 } \\
\text { 㟧 }\end{array}$ & $\begin{array}{l}b \\
\dot{b} \\
\stackrel{0}{0}\end{array}$ & $\begin{array}{l}\stackrel{0}{\tilde{\omega}} \\
\stackrel{\sigma}{0}\end{array}$ & $\begin{array}{l}\circ \\
\dot{\omega} \\
\stackrel{\sim}{\sim}\end{array}$ & - & 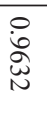 & $\begin{array}{l}\text { N } \\
\text { :i } \\
\text { o }\end{array}$ & $\overrightarrow{u_{1}}$ & U⿳亠丷厂 \\
\hline 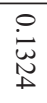 & $\begin{array}{l}\circ \\
\stackrel{\sim}{\sim} \\
\stackrel{\perp}{n}\end{array}$ & $\begin{array}{l}0 \\
\stackrel{0}{\omega} \\
\stackrel{N}{N}\end{array}$ & $\begin{array}{l}\stackrel{0}{ } \\
\dot{厶} \\
\infty \\
\infty\end{array}$ & $\begin{array}{l}\dot{\sim} \\
\stackrel{\sim}{\sim}\end{array}$ & $\stackrel{\stackrel{\sim}{\sim}}{\underset{N}{\sim}}$ & $\begin{array}{l}\stackrel{0}{0} \\
\text { ఏ్టे }\end{array}$ & - & $\begin{array}{l}\stackrel{\circ}{\circ} \\
\text { 岕 }\end{array}$ & $\begin{array}{l}\text { N } \\
\text { in } \\
\text { o }\end{array}$ & $\overrightarrow{i_{i}}$ & $\stackrel{\infty}{\circ}$ \\
\hline$\stackrel{\circ}{\stackrel{\vec{t}}{0}}$ & $\stackrel{\circ}{\stackrel{\vec{t}}{*}}$ & 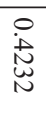 & $\begin{array}{l}\text { ㅇ } \\
\dot{a} \\
\text { }\end{array}$ & $\begin{array}{l}\dot{b} \\
\text { du }\end{array}$ & $\begin{array}{l}\stackrel{0}{\sigma} \\
\stackrel{\mathscr{L}}{\sigma}\end{array}$ & $\begin{array}{l}\text { 응 } \\
\text { 岕 }\end{array}$ & - & $\begin{array}{l}\text { ० } \\
\text { 怘 } \\
\text { 㟧 }\end{array}$ & $\begin{array}{l}N \\
\text { in } \\
\text { o }\end{array}$ & $\overrightarrow{i r}$ & ㅎㅇㅇ \\
\hline 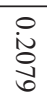 & $\begin{array}{l}\stackrel{0}{\tilde{\sigma}} \\
\underset{\sigma}{0}\end{array}$ & $\begin{array}{l}0 \\
\dot{\omega} \\
\stackrel{D}{0} \\
\end{array}$ & $\begin{array}{l}\stackrel{\circ}{\hat{\sigma}} \\
\dot{0}\end{array}$ & $\begin{array}{l}\dot{b} \\
\text { i } \\
\text { W }\end{array}$ & $\begin{array}{l}\stackrel{0}{\mathcal{U}} \\
\underset{\sim}{U}\end{array}$ & 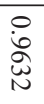 & - & $\begin{array}{l}\stackrel{\circ}{0} \\
\text { 岕 }\end{array}$ & $\begin{array}{l}N \\
\dot{a} \\
\dot{O} \\
\dot{O}^{\circ}\end{array}$ & is & है \\
\hline
\end{tabular}

\begin{tabular}{|c|c|c|c|c|c|c|c|c|c|}
\hline 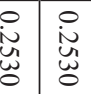 & \begin{tabular}{l}
$\dot{0}$ \\
$\dot{\omega}$ \\
$\dot{\alpha}$ \\
\multirow{2}{*}{}
\end{tabular} & $\stackrel{\circ}{\dot{\omega}}$ & 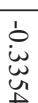 & $\underset{\stackrel{\sim}{\omega}}{\stackrel{\sim}{\sim}}$ & $\begin{array}{l}\text { O } \\
\text { 岕 }\end{array}$ & - & 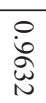 & $\begin{array}{l}N \\
\ddot{\ddot{O}} \\
\text { ö }\end{array}$ & $\overrightarrow{u r}$ \\
\hline
\end{tabular}

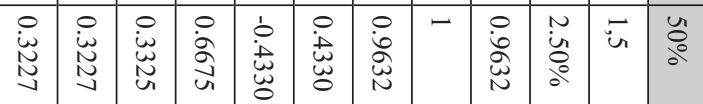

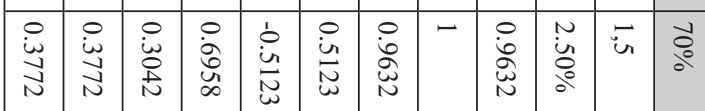

\begin{tabular}{|c|c|c|c|c|c|c|c|c|c|c|c|}
\hline$\stackrel{\circ}{\stackrel{0}{8}}$ & $\begin{array}{l}\stackrel{0}{0} \\
\dot{0} \\
\dot{0}\end{array}$ & $\begin{array}{l}\stackrel{0}{i} \\
\text { : } \\
0\end{array}$ & 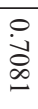 & $\begin{array}{l}\dot{b} \\
\text { ù } \\
\text { ث̀ }\end{array}$ & 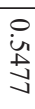 & 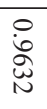 & - & $\begin{array}{l}\stackrel{8}{0} \\
\stackrel{\sim}{\mathbf{N}}\end{array}$ & $\begin{array}{l}N \\
\stackrel{N}{0} \\
\stackrel{0}{\circ}\end{array}$ & $\overrightarrow{u r}$ & $\stackrel{0}{\circ}$ \\
\hline 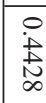 & $\begin{array}{l}\stackrel{\circ}{+} \\
\stackrel{+}{+} \\
\stackrel{\infty}{\infty}\end{array}$ & $\begin{array}{l}\stackrel{\circ}{\text { U }} \\
\text { O }\end{array}$ & $\begin{array}{l}\stackrel{\circ}{\mathbf{N}} \\
\stackrel{\mathbb{U}}{\mathrm{O}}\end{array}$ & $\stackrel{\dot{D}}{\stackrel{1}{N}}$ & $\begin{array}{l}\stackrel{\circ}{\hat{\sigma}} \\
\stackrel{+}{+}\end{array}$ & $\begin{array}{l}\circ \\
\dot{\leftrightarrow} \\
\stackrel{\leftrightarrow}{\sim}\end{array}$ & - & $\begin{array}{l}\stackrel{\circ}{\circ} \\
\text { 岕 }\end{array}$ & $\begin{array}{l}N \\
\ddot{O} \\
\dot{0}\end{array}$ & $\bar{u}_{n}$ & ఠ \\
\hline
\end{tabular}


The effect of uncertainty on the company value and measuring uncertainty are still unexploited research areas. In connection with the study of volatility, it would be interesting to examine the effective, value-creating region of volatility in case of companies in different sectors and with different business models. Another research question could be related to the optimal level of uncertainty, where it is worth to apply the Black-Scholes option pricing model. Besides these two option pricing methods the Geske's option valuation model could and should be introduced to the analysis to solve the simple option pricing model's undervaluation problem.

\section{CONCLUSION}

This paper applied the real option theory to venture capital businesses to detect the advantages of using real options as a way of thinking and evaluation method. According to the literature review, the characteristics of venture capital investments, such as a high degree of uncertainty, active management and partial irreversibility make it possible to use the real option approach. With the help of a case study, it was illustrated that the real option evaluation methods could identify the embedded flexibility in venture capital investments. To compare the two real option evaluation methods, the Black-Scholes model and the binomial pricing model, the latter resulted in higher option value that can relate to added value of staging. Besides the real option valuation, the value drivers of Black-Scholes model were analyzed through sensitivity analysis, and the highest impact has the present value of the underlying assets on the option value. This means in the case of venture capital investments that the present value of the company calculated with DCF method influences mostly the real option value. The volatility analysis confirmed that real options are valuable at high degree of uncertainty, which exists in the case of venture capital investments. 


\section{REFERENCES}

Adetunji, O. \& Owolabi, A. (2016), “The Evolution of Real Options and its Applications in Management: A Review of Literature." The International Journal of Business and Management, 4(1), 98-118.

Adler, R. W. (2000), "Strategic Investment Decision Appraisal Techniques: The Old and the New." Business Horizons, 43(6), 15-22. DOI: 10.1016/ s0007-6813(00)80017-8

Boyer, M., Christoffersen, P., Lassere, P. \& Pavlov, A. D. (2003), Value Creation, Risk Management, and Real Options, Centre for Interuniversity Research and Analysis on Organisations [on-line]. CIRANO, CIRANO Burgundy Reports. 3. https:// www.researchgate.net/publication/4816345 Value_creation_risk_management_and_real options (dowloaded: 2018.10 .02 ),

Brealey R. - Myers, S. (2005), Principles of Corporate Finance. 8th Edition, Boston, Irwin/ Mcgraw-Hill.

Bygrave, W., Fast, N., Khoylian, R., Vincent, L. \& Yue, W. (1989), "Early Rates of Return of 131 Venture Capital Funds Started 1978-1984." Journal of Business Venturing, 4(2), 93-105. DOI: 10.1016/0883-9026(89)90024-4

Carvalho, A. G., Calomiris, C., \& Matos, J. A. (2005), "Venture Capital as Human Resource Management." NBER Working Paper Series, National Bureau of Economic Research. Cambridge, 2005 May.

Cassar, G. (2004), "The Financing of Business Startups." Journal of Business Venturing, 19(2), 261283. DOI: 10.1016/s0883-9026(03)00029-6

Copeland, T. E. \& Antikarov, V. (2001), Real Options. A Practitioner's Guide. New York, Texere, 372 p.

Cox, J. C., Ross, S. A. \& Rubinstein, M. (1979), "Option Pricing: A Simplified Approach." Journal of Financial Economics, 7(3), 229-263.

Csapi V. (2018), „A reálopciók első 40 éve”, Vezetéstudomány, 49(9), 34-45. DOI: 10.14267/ veztud.2018.09.03

Csapi, V. (2019), "Real Options Application in Practice: A Text Mining Based Analysis." International Jounal of Multidisciplinarity in Business and Science, 5(8), 39-47.

Dahiya, S. \& Ray, K. (2012), "Staged Investments in Entrepreneurial Financing." Journal of Corporate Finance, 18(5), 1193-1216. DOI: 10.1016/j. jcorpfin.2012.07.002

Davis, M., Schachermayer, W. \& Tompkins, R. G. (2004), The Evaluation of Venture Capital as an Instalment Option: Valuing Real Options Using Real Options. In: Dangl T., Kopel M., Kürsten W. (eds) Real Options, ZfB-Ergänzungshefte: Gabler Verlag, Wiesbaden pp. 77-96.
Dean, J. (1951), Capital Budgeting. New York, Columbia University Press, 174 p.

Dixit, A. \& Pindyck, R. (1994), Investment Under Uncertainty. Princeton, NJ: Princeton University Press, $476 \mathrm{p}$.

European Business Angel Network (EBAN) (2009), Introduction to Business Angels and Business Angels Network Activities in Europe. Brussels: EBAN.

Fried, V. H. \& Hisrich, R. D. (1994), "Toward a Model of Venture Capital Investment Decision Making." Financial Management, 23(3), 28-37. DOI: $10.2307 / 3665619$

Gompers, P. A. (1995), "Optimal Investment, Monitoring, and the Staging of Venture Capital." The Journal of Finance, 50(5), 1461-1489. DOI: $10.2307 / 2329323$

Gompers, P. \& Lerner, J. (1999), The Venture Capital Cycle. Cambridge: The MIT Press.

Gong, P., He, Z. \& Meng, J. (2006), 'Time-dependent Volatility Multi-stage Compound Reap Option Model and Application." Journal of Industrial Engineering and Engineering Management, $1-14$.

Hartmann, M. (2006), Realoptionen als Bewertungsinstrument für frühe Phasen der Forschung und Entwicklung in der pharmazeutischen Industrie. Genehmigte Dissertation. Berlin, (Technische Universität Berlin), 256 p.

Hayes, R. H. \& Abernathy, W. J. (1980), ’Managing Our Way to Economic Decline." Harvard Business Review, 58(4), 67-77.

Herder, P. M., de Joode, J., Ligtvoet, A., Schenk, S. \& Taneja, P. (2011), "Buying real options. Valuing uncertainty in infrastructure planning." Futures, 43(4), 961-969. DOI: 10.1016/j. futures.2011.06.005

Huang, Y. \& Chou, S. (2006), "Valuation of Minimum Revenue Guarantee and the Option to Abandon in BOT Infrastructure Projects." Construction Management and Economics, 24(4), 379-389. DOI: 10.1080/01446190500434997

Jägle, A. J. (1999), ”Shareholder Value, Real Options, and Innovation in Technology Intensive Companies." R\&D Management, 29(3), 271-288. DOI: 10.1111/1467-9310.00136

Ko, C., Lin. T. T. \& Yang, C. (2011), "The Venture Capital Entry Model on Game Options with Jump-diffusion Process." International Journal of Production Economics, 134, 87-94. DOI: 10.1016/j.ijpe.2011.02.016

Kogut, B. \& Kulatilaka, N. (2001), “Capabilities as Real Options.” Organization Science, 12(6), 744 758. DOI: $10.1287 /$ orsc.12.6.744.10082

Kogut, B. \& Kulatilaka, N. (1994), "Operating Flexibility, Global Manufacturing, and the Option Value of a Multinational Network." Management Science, 40(1), 123-139. 
Landier, A. (2002), Startup Financing: From Banks to Venture Capital. Working Paper - Massachusetts Institute of Technology.

Landström, H. (2007), Handbook of Research on Venture Capital. Cheltenham, U.K.: Edward Elgar Publishing Ltd.

Lee, J. (2018), Venture Capital and Firm Performance. The Korean Experience in a Global Perspective. New York: Routledge.

Li, Y. (2008), "Duration Analysis of Venture Capital Staging: A Real Options Perspective." Journal of Business Venturing, 23(5), 497-512. DOI: 10.1016/j.jbusvent.2007.10.004

Lorenz, A. (1989), Venture Capital Today. London: Woodhead Faulkner.

Luehrman, T. A. (1998), "Investment Opportunities as Real Options: Getting Started on the Numbers." Harvard Business Review, 760(7-8), 51-67.

Maula, M. V. J. (2007), Corporate Venture Capital as a Strategic Tool for Corporations, In: Metrick, A., \& Yasuda, A. (2011), Venture Capital and the Finance of Innovation. Hoboken, New Jersey (USA): John Wiley \& Sons

Miltersen, K. \& S. Schwartz, E. (2004), "R\&D Investments with Competitive Interactions." Review of Finance, 8(3), 355-401. DOI: 10.3386/w10258

Park, C. S. \& Herath, H. S. B. (2000), „Exploiting Uncertainty-Investment Opportunities as Real Options: A New Way of Thinking in Engineering Economics." The Engineering Economist, 45(1), 1-36. DOI: $10.1080 / 00137910008967534$

Pennings, E., \& Lint, O. (1997), „The Option Value of Advanced R\&D." European Journal of Operational Research, 103(1), 83-94.

Pless, J. \& Arent, D. J., Logan, J., Cochran, J., Zinaman, O. (2016), "Quantifying the Value of Investing in Distributed Natural Gas and Renewable Electricity Systems as Complements: Applications of Discounted Cash Flow and Real Options Analysis with Stochastic Inputs.” Energy Policy, 97, 378-390.

Rózsa A. (2004), „Stratégiai beruházások reálopciós megközelítése." Vezetéstudomány, 35(2), 53-61.

Sahlman, W. A. (1990), "The Structure and Governance of Venture Capital Organizations." Journal of Financial Economics, 27, 473-521. DOI: $10.1016 / 0304-405 \times(90) 90065-8$

Schulmerich, M. (2010), Real Options Valuation: The Importance of Interest Rate Modelling in Theory and Practice. 2nd Edition, Berlin, Springer, 389 p.

Scialdone, P. (2007), Valuing Managerial Flexibility: Challenges and Opportunities of the Real Option Approach in Practice. Göttingen, Cuvillier Verlag, $309 \mathrm{p}$.

Seppa, T. J. \& Laamanen, T. (2001), "Valuation of Venture Capital Investments: Empirical Evidence." $R$ and D Management, 31(2), 215-230.
DOI:10.1111/1467-9310.00211

Smith, J. E. \& McCardle, K. F. (1999), "Options in the Real World: Lessons Learned in Evaluating Oil and Gas Investments." Operations Research. 47(1), 1-15. DOI: 10.1287/opre.47.1.1

Sung, T. \& Park, H. (2017), "Elaboration of Real Options Model and the Adequacy of Volatility." Asian Journal of Innovation and Policy. 6(2), 225-244.

Takács, A. (2014), "The Relationship between Appraised Company Values and Future Stock Prices in the International Banking Sector." International Research Journal of Finance and Economics, 9(118), 113-123.

Triantis, A. \& Borison, A. (2001), "Real Options: State of The Practice." Journal of Applied Corporate Finance, 14(2), 8-24.

Trigeorgis, L. (1993), "The Nature of Option Interactions and The Valuation of Investments with Multiple Options." Journal of Financial and Quantitative Analysis, 28(1), 1-20. DOI: $10.2307 / 2331148$

Trigeorgis, L. (1996), Real Options: Managerial Flexibility and Strategy in Resource Allocation. Cambridge, MIT Press, $427 \mathrm{p}$.

Trigeorgis, L. \& Reuer, J. J. (2017), "Real Options Theory in Strategic Management." Strategic Management Journal, 38 (1), 42-63.

Tyebjee, T. \& Bruno, A. (1984), "A Model of Venture Capitalist Investment Activity," Management Science, 30, 1051-1066. DOI: 10.1287/ mnsc.30.9.1051

Wang, K. \& Zhou, Y. (2006), "Equilibrium Real Options Exercise Strategies with Multiple Players: The Case of Real Estate Markets." Real Estate Economics, 34(1), 1-49. DOI: 10.1111/j.15406229.2006.00158.x

Willner, R. (1995), Valuing Startup Venture Growth Options. In: Trigeorgis, L. (1996) (ed.): Real Options in Capital Investment - Models, Strategies and Applications, Westport: Praeger. 221239.

Wright, M., Lockett, A., Pruthi, S., Manigart, S., Sapienza, H., Desbrieres, P. \& Hommel, U. (2004), "Venture Capital Investors, Capital Markets, Valuation, and Information: US, Europe, and Asia." Journal of International Entrepreneurship, 2(4), 305-326. DOI: 10.1007/s10843-004-0131-0

Wright, M. \& Robbie, K. (1996), "Venture Capitalist and Unquoted Equity Investment Appraisal." Accounting and Business Research, 26(1), 153168. DOI: $10.1080 / 00014788.1996 .9729506$

Yeo, K. T. \& Qui, F. (2003), "The Value of Managerial Flexibility - a Real Option Approach to Investment Evaluation." International Journal of Project Management, 21(4), 243-250. DOI: $10.1016 / \mathrm{s} 0263-7863(02) 00025-\mathrm{x}$ 
Alexandra Posza, Assistant Lecturer poszaa@ktk.pte.hu University of Pécs

Faculty of Business and Economics 